\title{
Solutions to Teacher Absenteeism in Rural Government Primary Schools in India: A Comparison of Management Approaches
}

\author{
Krishna Narayan and Jos Mooij
}

International Institute of Social Studies, Erasmus University Rotterdam, The Netherlands

\begin{abstract}
Teacher absenteeism in government primary schools in rural India is a huge and well-documented phenomenon. Using Christopher Hood's cultural-theory framework of doing public management, this paper analyses this problem from four different perspectives, i.e. the hierarchist, egalitarian, individualist and fatalist management approach. The paper proceeds with a discussion of three innovative strategies currently proposed or pursued in India to deal with teacher absenteeism. These are 1) the creation of local-level institutions that could hold teachers accountable, 2) the creation of a voucher system to allow parents to choose the school (government or private) for their children, and 3) the recruitment of volunteers on contract basis to do a teaching job. These three strategies, the paper argues, can be interpreted as responses that fit, respectively, within an egalitarian, an individualist and a fatalist approach. The paper concludes that none of the four perspectives can be expected to provide 'quick fix' solutions, especially because they 'act on' teachers rather than 'act with' them. Teachers, it is argued, should get a larger role themselves in the formulation and implementation of a strategy to address teacher absenteeism.
\end{abstract}

Keywords: Teacher absenteeism, India, public management, government school, elementary education, primary education.

\section{INTRODUCTION}

More and more children go to primary schools ${ }^{1}$ in rural India. Since the late $1980 \mathrm{~s}$, and especially since the mid1990 s, enrolment rates have gone up considerably. On the one hand, parents have become more and more convinced of the value of education. On the other hand, there have been some major governmental efforts to bring all children to school, notably the District Primary Education Programme (DPEP) and the 'Education for All campaign' also known as Sarva Shiksha Abhiyan (SSA). By 2003-04, more than 94 per cent of the estimated 210 million children in the age group of 6-14 years were reported to be enrolled in schools (MHRD GoI, 2006) [1]. The large majority of these children go to government schools, though the importance of private fee-charging schools is rapidly increasing. Almost all the socalled 'first generation learners' access government schools. The closing of the educational gap, hence, depends to a large extent on the quality of education in these schools.

Unfortunately, there are major problems with rural government primary schools in the country. A recent nationwide survey in rural India found that overall, 40 per cent of students studying in class five in government schools could not read a class two text and 58 percent could not solve simple division sums (Pratham 2006) [2]. Children may, hence, complete primary schooling without having acquired the expected literacy and numeracy skills.

*Address correspondence to this author at the International Institute of Social Studies, Erasmus University Rotterdam, The Netherlands; Tel: 0031(0) 70 4260610; Fax: 0031(0) 70 4260799; E-mail: mooij@iss.nl

${ }^{1}$ In most Indian States, primary schooling is from classes one to five; the elementary cycle is from class one to eight. Typically, in rural areas the entry age into class one is around 6 years.
One of the problems, and the main focus of this paper, is teacher absenteeism. As has been reported in many studies, there is a problem with (unauthorized) teacher absenteeism in many parts of the country (Mehrotra 2006) [3] (PROBE Team 1999) [4]. The most recent authoritative study on teacher absenteeism in the country is the World Bank National Absence Survey (WBNAS). Making unannounced multiple visits to 3700 government primary schools across 20 States within India, 35,000 observations on teacher attendance were collected. Overall, 25.2 per cent or roughly one in four teachers were found to be absent in rural areas. ${ }^{2}$ Official non-academic duties accounted for only four per cent of the total absences and ten per cent of absences were on account of officially sanctioned leaves. ${ }^{3}$ The PROBE restudy conducted in 2006 found that in the course of ten years many things had improved (i.e. enrolment, school infrastructure, school incentives, school meals etc.) but classroom activity had not (Shiva Kumar 2009) [6].

In an attempt to explain the high level of unauthorized teacher absenteeism, several scholars have emphasised the lack of motivation on the part of the teachers. This has been ascribed to overcrowded classrooms, poor infrastructural facilities, unfilled vacancies, burden of non-academic tasks, lack of adequate training to deal with multi-lingual and multi-ability classes, declining social status of the teaching profession and increasing social class differences between teachers and the clientele of government schools. Other reasons have to do with the institutional context: lack of

\footnotetext{
${ }^{2}$ Significant inter-State variations were found in this study (Kremer 2005) [5]. The absence rate varied from 14.6 per cent in Maharashtra (the lowest) to 41.9 per cent in Jharkhand (the highest).

${ }^{3}$ Pratham (2006) [2] also found a similar teacher absence rate of 25 per cent in rural areas in the whole of India.
} 
accountability and the absence of incentives for teachers to work well. ${ }^{4}$

What can be done about teacher absenteeism? Since our focus is on teachers in government schools, teacher absenteeism is a public management problem. What is it that those who manage government school teachers can do to reduce teacher absenteeism? In this paper, we discuss the various public management responses that can be developed to deal with the problem. In this discussion, we use Christopher Hood's cultural-theory framework of doing public management. Based on the work of Mary Douglas, this framework distinguishes four different approaches of doing public management. In the next section we will describe these approaches. In the third section we will apply them to the problem of teacher absenteeism in India. We will discuss how teacher absenteeism can be interpreted in different ways, and how these interpretations lead to different public management responses. The fourth section will provide a review of the literature of three solutions that have been advocated or tried in the Indian context. The paper will end with some comparative notes regarding the four management responses, and will conclude that what misses in all four is the active involvement of teachers themselves.

\section{HOOD'S FRAMEWORK OF PUBLIC MANAGEMENT STYLES}

Hood (1998) [7] distinguishes the four following approaches for dealing with public management problems: the hierarchist, the egalitarian, the individualist and the fatalist approach. ${ }^{5}$ All these approaches are essentially about control and regulation, but they try to achieve this in different ways. Public management in the hierarchist way is characterized by strict relations of authority. Ideally, organisations have a clear hierarchical structure and a clear division of responsibilities. The assumption is that such organisations provide the best guarantee that everybody will do his/her job - and that slackness or shirking can be controlled. There is a strong belief in well-understood (not necessarily written down) rules and rule-like behaviour. When things go wrong, it is always clear who is to be blamed: the person(s) who did not follow the rules (Hood 1998: 74) [7]. When managerial problems crop up, the normal course of action is to clarify the lines of authority and strengthen the role of the formal overseers. This is the traditional way in which public management problems have been tackled in many government bureaucracies, including the Indian one.

Doing public management the egalitarian way, on the other hand, is characterized by cooperation and participation. Unlike hierarchists, egalitarians believe in the desirability and possibility of self-organisation and self-steering processes. When things go wrong, egalitarians tend to see 'the self-serving behaviour at the top' as the root of the problem (Hood 1998: 122) [7]. The egalitarian mode of controlling organizations is through mutuality and 'maximum face to face accountability' (Hood 1998: 122)

\footnotetext{
${ }^{4}$ See, for instance (Govinda 2005) [8] (Mooij 2008) [9] (Ramachandran 2005) [10]. For more arguments and references, see (Narayan 2007) [11]. ${ }^{5} \mathrm{An}$ alternative framework for understanding organisational relationships is available, that is similar to Hood's different approaches, except that the fatalist management style is not included. (Robinson 2000) [12].
}

[7]. Based on the subsidiarity principle, decentralized local self governing units are thought to be the best guarantee for meaningful bottom-up participatory management.

An individualist approach to public management is based on the assumption that human beings are essentially 'rational egoists' (Hood 1998: 98) [7]. In principle, they pursue their own interests, but the way they do this and what their interests are can be influenced by an institutional context providing incentives and disincentives for particular behaviour. This insight can be applied to people working within the government, but also to clients. The first focus would try to enhance performance by making people within the government compete for positions, money, assignments or prizes. A focus on clients as rational actors comes with the belief that there should be competitive provision of public services. Only when clients have choice, providers are forced to offer better quality, become more responsive, efficient and less costly.

In the fatalist way of doing public management, the idea is that there are no effective checks on the actions of public officials. This leads to a vicious circle: because there is no faith in effective checks on public office holders, no attempts are made to create a more stimulating environment for them. It is assumed that officials almost always perform poorly, are corrupt and since they generally do not have to account for their behaviour, they are able to get away with it. The result is widespread public cynicism about the motives and honesty of government officials. The expectations are low, which leads to a lack of interest to organise collectively for better checks and control (Hood 1998: 147-8) [7]. The question that can be raised, of course, is whether this attitude is a management approach at all. Indeed, as Hood (1998: 145-7) [7] describes, there have been many theorists who have left fatalism out of their discussion of management styles. Hood, however, maintains that although the attitude is 'negative', it is common. Many managers, he argues, believe that public organisation and policy are essentially unpredictable and chaotic processes and that responses are often more ad hoc than being based on a clear-cut theory - although most managers may express this opinion only 'off the record'. In relation to our topic - teacher absenteeism in India - we think that this approach is quite relevant.

\section{MANAGEMENT STYLES AND TEACHER ABSENT- EEISM}

The four approaches are based on different assumptions about organisations and human behaviour within organisations. When applied to the problem of teacher absenteeism, they lead to different hypotheses explaining the problem, different lines of research and different types of recommendations. Indeed, we can see that reflected in the various interpretations of the phenomena of teacher absenteeism in India. See Table $\mathbf{1}$ for a summary of the four approaches.

From a hierarchist position, it would be argued that periodic supervision and monitoring are necessary to support teachers to carry out their work well and to control teacher absenteeism. Officially such support and inspection exists in government schools in India. Several studies reveal, however, that many schools are not inspected on a regular basis. There may be a shortage of supervisory staff, or 
Table 1. Management Styles and Teachers Absenteeism

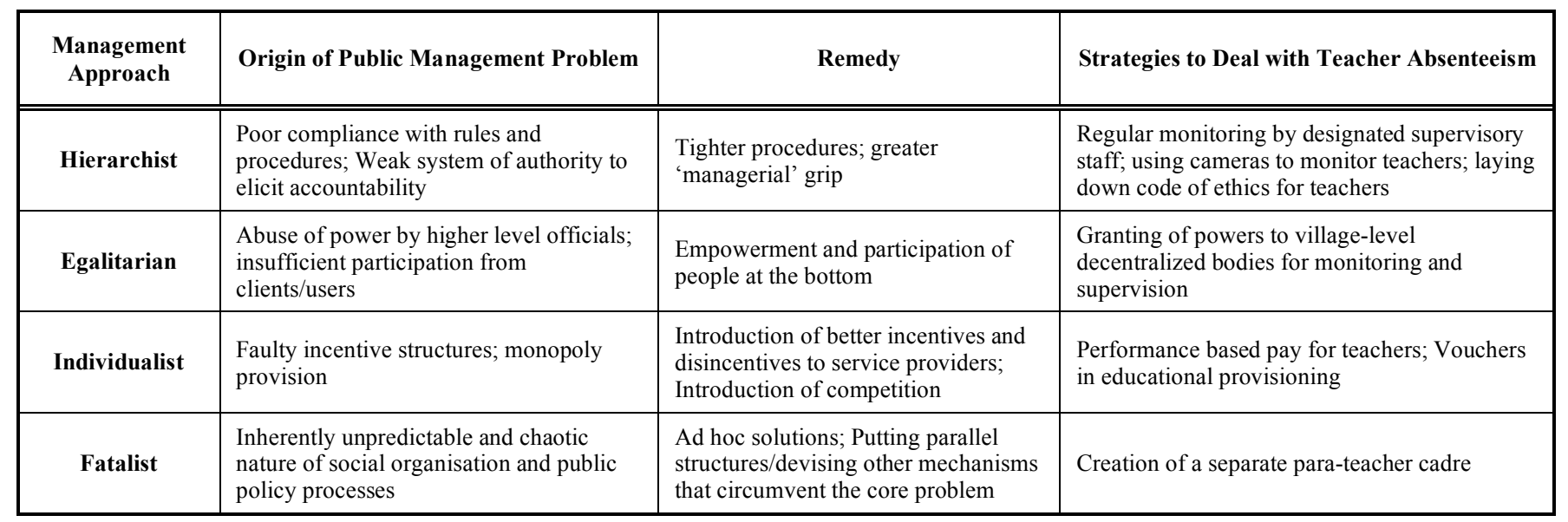

supervisory staff may lack the capacity to carry out proper supervision (Clarke and Jha 2006) [13] (Grover and Singh 2002) [14]. Frequency of inspection was found to be correlated to absenteeism, confirming the view that regular monitoring is important (Kremer 2004) [15]. Mooij (2008) [9] also found that lack of serious supervision and appreciation from inspectors and others higher up in the educational bureaucracy contributed significantly to low levels of motivation.

Solutions that fall within this management style are an intensification of inspection. One idea that has been tried in rural Udaipur in Rajasthan is using cameras with tamperproof time and date functions. Teachers were required to take their snap along with students at the start and close of each school day. Together with other measures (a bonus in addition to the base salary contingent on presence, and a fine in case of absence), the experiment led to a decline in the teacher absence rate from 44 per cent to 27 per cent in a period of 27 months. The test scores of students also improved (Duflo and Banerjee 2006) [16]. ${ }^{6}$ Mehrotra's (2006) [15] suggestion of having a Teacher's Code of Professional Ethics with sanctions against teachers violating the code also falls within this approach.

Comparable to hierarchists, egalitarianists also attribute teacher absenteeism to an accountability failure. Their emphasis is, however, not on accountability upwards within the same organisation, but on accountability outwards, viz towards the parents or the wider community. In India, there have been many studies that have observed that this downward/outward accountability relationship is, indeed, lacking in fundamental ways. Others relate this to the rise of private schooling and the exit (Hirschman 1970) [17] of the more well-to-do and educated parents from the government schools. (Majumdar and Mooij forthcoming) [18]. Their departure invariably means that government schools loose the kind of clientele that could monitor school quality and complain in case they are dissatisfied.

The logical solution that follows from the egalitarian approach is to foster and strengthen the school-community link through school management committees, parent-

${ }^{6}$ In 2006, this experiment was conferred the 'ICT Digital Learning Innovation Award'. teachers associations or other local-level educational bodies. This strategy has been tried in many States in India and we will discuss it in more detail in the next section.

For individualists, the problem has to do with the way in which individual choices and behavioural patterns are structured or constrained. Firstly, the focus can be on teachers themselves and the failing incentive structure. It is argued that within the elementary educational system, there are typically no incentives for teachers to perform well (Ramachandran 2005) [10]. A well-defined performance appraisal system is virtually absent and primary school teachers have negligible prospects for promotion (Jha 2001) [19] (World Bank 1997) [20]. Promotions and increments depend on seniority rather than performance (Rao 2003) [21]. Non-monetary incentives like prizes and awards have been used to motivate teachers, but over the years, the selection of candidates has become politicized and independent of performance (Ramachandran 2005) [10]. All this means that there are virtually no sanctions in place for teacher absenteeism. In more than 3000 interviews with headmasters, only one instance was found wherein a teacher had been fired because of absenteeism (Kremer 2005) [5].

The logical solution here would be to link the salary of teachers to their presence. In India, as far as we know, this has only been tried in the above mentioned study in rural Rajasthan, where, together with the help of cameras, this led to a considerable reduction in teacher absenteeism. Given the normal public service conditions and the power of teacher unions, it is unlikely that payment to regular teachers in government schools will move towards a performance-based salary structure. Penalizing teachers for their absence by withholding their allowances or even suspension is possible, but difficult in practice - again because teacher unions are strong and politically influential (Kremer 2006) [22] (Kingdon and Muzammil 2001) [23].

Secondly, the focus can be on clients, i.e. those who seek education. In this case, the individualist's solution would be to enhance school choice. In principle, this choice exists already. There is a rapidly increasing number of private feecharging or NGO-run schools. Many of these schools have a monthly fee that does not exceed the income that a daily wage labourer would earn in one day. They generally cater to the children from the lower middle classes. These so- 
called Low Fee Private schools should be stimulated, according to the advocates of competition in education, for instance by introducing a voucher system (Tooley and Dixon 2003) [24]. This would mean that parents would get an ' $x$ ' amount of money in the form of school vouchers. They would be allowed to use these vouchers in any school of their liking. Although this system has only just been piloted in the country and the experiences are limited, we will discuss the idea in greater detail below.

Lastly, a fatalist approach to teacher absenteeism would be to resort to cynicism or to decline responsibility altogether. Rather than assuming responsibility for the various problems that plague the educational sector, there is 'governance by resignation, privatisation by default' (Mooij and Jalal 2009) [25]. The currently popular response to recruit para-teachers (or volunteers) could also be interpreted within this framework. Para-teachers are unqualified teachers. They generally have 10 or 12 years of schooling (i.e. completed secondary school) plus a few days of training. Their salary is often around Rs. 1000-2000 (i.e. 2040 euros) per month, which is much less than the monthly income of an average government teacher, and they are hired on contract basis. ${ }^{7}$ This is the third innovative strategy that will be discussed below.

\section{DEALING WITH TEACHER ABSENTEEISM: A REVIEW OF EVIDENCE}

In this section we review the literature regarding three different strategies to overcome teacher absenteeism: the establishment of local educational committees, the educational voucher system and the introduction of parateachers. All these strategies are relatively recent. The more traditional way, as we have mentioned already, is by resorting to hierarchist methods. We leave this out of the discussion precisely because these methods belong to the more conventional management style. Two of the three solutions discussed here have been introduced on a wide scale and there is a lot of literature reviewing the experiences. The third, the voucher system is a new idea that has only just been introduced on a pilot basis but that is gaining momentum. At the outset it should also be made clear that these three strategies have multiple objectives and are not initiated solely to address the problems of teacher absenteeism. For example the strategy of creating a separate cadre of para-teachers also had the objective of reducing expenditure on teacher salaries.

\section{The Egalitarian Way: Decentralized Village Level Institutions}

There are two ways through which local school management can take place. One is through the elected bodies that exist at the local level. Beginning from 1993, State governments are legally obliged to transfer many functions previously managed and monitored at the State level to local level elected bodies, the so-called Panchayati

\footnotetext{
${ }^{7} \mathrm{We}$ realise that there is an alternative interpretation that would regard the introduction of para-teachers as a sign of hope rather than as a sign of fatalism; after all, the idea is that this intervention would help to address the malaise. We classify it here as a fatalist response because the introduction of para-teachers on a large scale signifies a choice not to reform the existing human resources system within the Department of Education but to establish a parallel cadre.
}

Raj Institutions (PRIs). Primary education is one of these activities that, according to this legislation, should be managed at the local level. The other way is through the creation of specific user group committees. These committees can exist at the level of the school (such as a school education committees - or SECs) or at the level of the village (such as a village education committee - or VECs). These committees have been stimulated by the Sarva Shiksha Abhiyan, which emphasizes the potentially large and positive role of these community institutions in school supervision, micro-planning, construction and maintenance, learning improvement activities and utilization of funds.

There are successful instances of both forms of decentralization. Madhya Pradesh is seen by many as a pioneer of decentralization. This State has relatively low levels of teacher absenteeism (17.6 per cent), which is understood by some as a positive effect of democratic decentralization (Mehrotra 2006) [3], (World Bank 2004) [26]. A similar positive effect of decentralization is reported from Karnataka (Drèze and Sen 2002) [27] (Ghosh 1992) [28]. The most acclaimed process of empowering Village Educational Committees was undertaken by the State of Nagaland. In response to teacher absenteeism, the government passed the 'Communitisation of Nagaland Public Institutions and Services Act' in 2002 (Rio 2005) [29] and granted significant powers to this body. An Impact Assessment carried out by UNICEF in 2004 revealed that teacher attendance improved to 90 per cent in 18 of the 28 sample schools. ${ }^{8}$

These positive examples are, however, exceptional. The evidence from most other States is less encouraging. A sample survey of 14 States (covering all the regions of the country) to study the involvement of PRI bodies in primary education was carried out by the NGO PRIA in 2002. The findings revealed that in the majority of the States, PRI bodies are not authorized to initiate any disciplinary action against poorly performing teachers, even though they have been vested with the powers to supervise the attendance of teachers. The only right that they often have is the right to complain to the higher authorities. In many cases, members have become disillusioned with the PRI institutions since disciplinary action is rarely taken against erring teachers. As a result, the PRIs were found to play only a marginal role with respect to teacher management (PRIA 2002) [30] ${ }^{9}$. The PROBE team (1999) surveying four northern States found VECs on the whole to be token institutions without useful supervisory functions The Second Joint Review Mission of the SSA implicitly supports this by acknowledging the need for greater empowerment of community institutions for effectively monitoring the functioning of schools (MHRD GoI, 2006) [1].

The observation that the link between decentralization and improved teacher performance in government schools is problematic (Bennell 2004) [31] seems to be true for the majority of the States. Effective functioning of local institutions is contingent upon the extent of powers and autonomy vested with them. In all States, critical functions

\footnotetext{
${ }^{8}$ This has been endorsed by the GoI as a good model which could be adopted by other States (MHRD GoI, 2006) [1].

${ }^{9}$ Their role in infrastructure provisioning and maintenance was found to be comparatively larger.
} 
in teacher management continue to rest with the State department. The local institutions may have come in to some extent, but they have never replaced the department (Pritchett and Pande 2006) [32]. Teachers are very well aware of the fact that the authority of the local bodies to punish them is limited (Duflo and Banerjee 2006) [16]. They have also actively opposed the decentralisation of teacher management functions to community level organisations (Vasavi 1997) [33]. In fact, as many observers have argued, the outright dismissive attitude of teachers towards 'egalitarian' accountability relations is one of the important challenges to be tackled in order to make this an effective strategy (Vaidyanathan and Nair 2001) [34].

Another major reason for the limited effectiveness of this strategy is the lack of awareness about the rights and powers bestowed upon PRIs or VECs/SECs. The PROBE restudy found numerous instances of committee members who were even unaware that they were listed as a committee member (Shiva Kumar 2009) [6]. PRI members in Haryana were hardly aware of the importance of the Annual Confidential Report (ACR) as a monitoring and supervision tool, though they are authorized to note their remarks in the ACR of teachers (PRIA 2002) [30]. In Kerala where the PRIs have been granted substantial powers, they demonstrate considerable involvement in infrastructure related aspects, but most of the activities related to teacher management (including hiring and firing of teachers) remain within the domain of the State government (Pritchett and Pande 2006) [32]. Even in the relatively successful State of Madhya Pradesh (MP), where the head of the village PRI body is mandated to sign the salary slip of the teacher as a mark of having verified his/her attendance, these heads often do so without having undertaken any kind of monitoring (Noronha 2003) [35] (Sharma 1997) [36]. Capacity building of the functionaries is of crucial importance (Drèze 2000) [37]. Unfortunately, not enough is done in this regard. Even after four years of implementation of SSA, at least 12 States were indicted by the Comptroller and Auditor General (CAG) of India for performing below par (in terms of coverage and quality) in imparting training to the VEC members in 200506 (CAG Reports 2006) [38]. It may, however, also be the case that some of the VEC/SEC members themselves are not interested in undergoing such training. In many States the members are nominated by local politicians or they are elected along party lines. In such cases, the committees may serve as stepping stones for would-be politicians (or structures through which local politicians can enhance their influence) rather than tools of community control (Reddy and Bhavani forthcoming) [39] (Powis 2003) [40] (Rana 2003) [41].

\section{The Individualist Way: The School Voucher System}

Unlike the other two strategies discussed above, the voucher system is not yet operational in the country, albeit it has been tried on a pilot basis ${ }^{10}$. This innovative idea is being pushed powerfully by the Centre for Civil Society (CCS), an independent non-profit research and educational organisation based in New Delhi. In January 2007, the CCS launched the so-called 'School Choice Campaign'. The basic premise is that the disparity in the quality of schooling could be best

\footnotetext{
${ }^{10}$ See www.ccs.in and www.schoolchoice.in.
}

addressed by giving parents a real possibility to choose the school their children would attend. A voucher system would guarantee such choice. This system implies that rather than schools receiving the money directly, parents are subsidized through vouchers. This voucher may cover the full costs of education or only a part of it. Parents give the voucher to the school of their choice, and the school can reclaim the money from the institution that has handed out the voucher. This idea has caught the attention of some policy makers and finds a mention in the draft approach paper to the $11^{\text {th }}$ Five Year Plan for the period ranging from 2007 till 2012 (Planning Commission GoI 2006) [42].

The advocates of the voucher system base themselves on legal as well as pragmatic arguments. The legal argument is that Article 26(3) of the Universal Declaration of Human Rights (1948) states that parents have the right to choose the kind of education they want for their children. Like in several other countries, in India also this right is violated since parental choice for many is restricted to poorly functioning government schools simply because private schools are unaffordable for them (Willmore 2004) [43]. The more pragmatic argument is that choice would result in government schools competing amongst themselves and government schools competing with private schools (Muralidharan 2006) [44]. This competition in turn would lead to quality improvement (Shah and Braun-Munzinger 2006) [45]. The system would also enhance accountability since parents who pay with their vouchers will demand quality education; if they are dissatisfied they would take their voucher back and leave the school. Teacher absenteeism would come down since teachers would be constantly scrutinized by parents (Balasubramanian 2003) [46].

Since the voucher system has only been piloted in India, there is not much evidence available about its effectiveness. So far as we know, there has been one evaluation of a voucher project which was implemented in New Delhi. ${ }^{11}$ In this pilot, the Centre for Civil Society awarded school vouchers worth up to Rs. 3600 Rs. per year to 408 students. The evaluation showed that the majority of the voucher beneficiaries ( 63 per cent) had made use of the possibility to exercise school choice, and had switched over from a government to a private school. On the whole, those who had received these vouchers were more satisfied than those who had not received such a voucher. It is unclear whether this voucher system only entailed a payment to the parents, or whether it also entailed a withdrawal of funds from the government schools. The evaluation also does not mention the effects of competition on school quality.

A voucher system only works if there are multiple suppliers. Hence, a relevant question is whether there are enough suppliers in rural areas to have real school choice. This may not be the case everywhere - although there is no doubt that the number of low fee private schools in rural areas is rapidly increasing. The ASER 2006 survey found that 18.6 per cent of all rural primary age children (7-10 years) in the sample were attending private schools (Pratham

\footnotetext{
${ }^{11}$ See 'Evaluation of the Delhi Voucher Project. Summary', downloadable from http://www.schoolchoice.in/events/20090219_ delhivvoucher_summ ary.php (accessed 6 March 2009)
} 
2007) [47]. Eight States had more than 30 per cent of children in private schools at the primary level. In another study, it was found that 28 per cent of the villages in the sample had access to a government school as well as a private unaided primary school, though there was considerable inter-state variation (Muralidharan and Kremer 2006) [48]. In all, these figures suggest that in the majority of the villages there is still only one provider - and a voucher system would hence not work. It is, however, not inconceivable that the introduction of a voucher system could somewhat change this scenario. It might well be that the system would stimulate private 'edupreneurial' activities.

Another crucial issue is related to quality assurance. About half of the village private schools observed by Muralidharan and Kremer (2006) [48] were unrecognised. They fall outside the regulatory system of the government, meaning that there is no government body responsible for quality control. Since a voucher system is likely to increase the number of unrecognised schools (in any case in the short run), the moot question then is how quality service delivery by these schools can be monitored and ensured. Some advocates of the voucher system have argued that this is not a problem; the voucher system would lead to competition and the laws of demand and supply would ensure that quality improves (Balasubramanian 2003) [46]. What kind of 'quality' this intensified competition will lead to remains a question. As Majumdar and Mooij (forthcoming) [18] argue, there are different forms of competition in the private schooling sector: the 'higher segment' catering to the elite and middle classes compete by setting high standards (in terms of exam results). They restrict admission to children who will do well in their exams and who hail from well off families. The 'lower' segment, however wants to attract more children to their schools, and they compete by concentrating on the more visible dimensions of quality: colourful and freshly painted classrooms, continuous activity in the schools, claims of English-medium instruction, homework for the children (even when they are very young), etc. Shukla and Joshi (2008) [49] refer to these features as 'staging education', rather than as expressions of real quality. It is very likely that the voucher system will enhance competition particularly in this lower segment, and that competition may therefore focus more on the visible signs of 'school activity' rather than on dimensions of the teaching and learning process itself. Quality monitoring by a regulatory body would remain necessary (Levin 2002) [50], (Lauglo 1995) [51]. ${ }^{12}$

A third crucial issue is related to the political feasibility. The idea of vouchers goes directly against the interests of government school teachers, who are a powerful and well organised group (Indiresan 2006) [52]. This makes implementation on a large scale a highly unlikely proposition.

\footnotetext{
${ }^{12}$ Majumdar and Mooij (forthcoming) [18] mention a second argument for a public regulatory body. If quality improvement depends exclusively on parents seeking the best opportunities for their children and the 'edupreneurial' activities within an increasingly dominant private sector, what is lost is the possibility of a larger public debate about the educational goals one wishes to achieve as a community - a public vision about educational quality.
}

\section{The Fatalist Way: Creation of a Separate Cadre of Para- Teachers}

Unlike regular teachers in government schools who have permanent tenure, para-teachers are recruited on a fixed term contract. They receive a relatively low remuneration when compared to the regular teachers (Pandey 2006) [53]. In most States, local bodies play an important role in the selection of para-teachers (Fyfe 2007) [54] and in the majority of cases, the para-teachers are local residents (Govinda and Josephine 2004) [55]. Rather than the official two year teacher training programme that is mandatory for regular primary teachers, para-teachers have a much shorter pre-service training programme. Almost half a million parateachers were appointed in 2005-06 across 35 States, of which 93 per cent were working in rural areas and 66 per cent were posted in primary schools (NUEPA 2007) [56].

Para-teachers can be hired for regular schools or for alternative schools (e.g. schools run by NGOs, schools set up by SSA or other programmes for specific groups, etc.). Initially the idea was that if para-teachers were recruited for regular schools, they would assist the regular teachers rather than teach themselves independently. In most cases, however, they function as normal teachers. The hiring of para-teachers in regular schools has an economic and a noneconomic rationale. The rising share of teacher salaries in educational expenditure combined with the increasing fiscal deficit faced by several State governments led to a freeze on the recruitment of regular teachers (Mehrotra and Buckland 2001) [57]. Recruitment of para-teachers was visualized as a low cost solution since they are appointed on one-fourth to one-fifth of the regular salary (Kumar 2001) [58]. The noneconomic argument for hiring para-teachers in regular schools is that a locally recruited person would be more accountable to the local population, would be less absent and hence perform better.

If para-teachers are recruited as a part of the solution for teacher absenteeism, the question arises whether their absence rate is lower than that of regular teachers. The evidence is mixed. On the one hand, studies in Madhya Pradesh (Bose and Chatterjee 2004)[59] and Uttar Pradesh (SIEMAT-UP 2005 cited in World Bank 2006) [60] found para-teachers to be less absent. On the other hand, WBNAS observed that para-teachers and regular teachers had roughly the same absence rate of about 24 per cent (Kremer 2005) [5]. Moreover, there is some evidence suggesting that regular teachers' absenteeism could increase after the appointment of para-teachers (Mehrotra and Buckland 2001) [57].

It may be that the record of para-teachers in alternative schools is better than in regular schools - something that could be related to the fact that there is a higher level of community involvement in these schools than in regular schools leading to more effective accountability relationships. A study conducted in West Bengal in 2002 showed that absenteeism among para-teachers in alternative schools was 43 per cent lower than that of teachers in regular primary schools (Pratichi Trust 2002) [61]. In a study on alternative schools in Madhya Pradesh it was found that though these schools were often functioning regularly (unlike many regular schools), the quality of education imparted by the para-teachers was problematically low (Leclercq 2002) [62]. Many scholars have observed that the 
training of para-teachers is often insufficient. For example in Andhra Pradesh, though the para-teachers were supposed to be given training for 30 days before they start, it was found that in six districts the training ranged from only three to seven days (CAG Report 2006) [38]. Overall the amount and quality of academic support provided to para-teachers by the monitoring personnel is low on both quantity and quality (Govinda and Josephine 2004) [55].

As mentioned already, para-teachers do not have a regular job, but have fixed term contracts (linked to the academic year). The argument of placing them on contract is that this would act as an incentive to perform better (Duthilleul 2005) [63]. Their commitment and lower absenteeism rates (when observed) can indeed perhaps be attributed to the impermanence of their contract, and it is believed that placing them on permanent contracts would make them indistinguishable from regular teachers (Mehrotra, 2004) [64]. In practice, however, there is hardly any framework for, or practice of, performance appraisal and most para-teachers get their contracts renewed (Duthilleul 2005) [63]. Moreover, their lack of job security can also decrease motivation and lead to absenteeism, (Kremer 2004) [15]. The low wages can be perceived as unfair and may even force para-teachers to take up secondary employment (Bennell 2004) [31] (Govinda and Josephine 2004) [55] (Leclercq 2002) [62] (Sharma 1999) [65].

The creation of a separate cadre of para-teachers has led to a diversification of the primary teacher status (Göttelmann-Duret 2000) [66]. It has been argued that the creation of multiple layers of teachers with varying service conditions could have a demoralizing impact on the entire teaching force. It has been observed that the trend of recruiting para-teachers has led to 'further degradation of the status of school teachers, thus diluting the identity of a teacher as a professional' (NCTE 2006: 19) [67]. Teachers unions, on the whole, are against para-teachers and have demanded the abolition of the scheme. Concerns are also expressed about the demand from para-teachers to be integrated in the mainstream. This would defeat the very purpose of this low cost solution and might contribute to a further weakening of the teacher cadre (PROBE Team, 1999).

In conclusion, there is little doubt that in some regular as well as alternative schools, the para-teachers have had some positive effects. There is evidence that in some cases, their absenteeism rate is less than that of regular teachers. As Drèze and Sen (2002) [27] have pointed out, it would therefore be unwise to completely dismiss this solution. Yet, on the other hand, in order for the scheme to work well, a more substantial investment would be needed for providing training and guidance (Mehrotra and Buckland 2001) [57]. The impact of para-teachers on the motivation and professional status of regular teachers also remains an important concern. It remains therefore unlikely that the hiring of para-teachers will turn out to be a simple fix for teacher absenteeism in the long run, even though it may be cost-efficient in the short run (Kremer 2004) [15] (Rogers 2004) [68].

\section{BY WAY OF CONCLUSION}

We started the paper with a description of the four different styles of public management - the hierarchist, the egalitarian, the individualist and the fatalist approach - based on Hood's cultural theory of public management. After a discussion of the implications of these styles for addressing the problem of teacher absenteeism, we zoomed in on three new policies and schemes that are meant - among other things - to address the problem of teacher absenteeism. Together with the more conventional solution (increasing monitoring and inspection) these constitute four alternative approaches, each fitting one of the management styles. We have shown that none of the solutions discussed has been really successful in addressing teacher absenteeism. It has become clear that, in order for the strategies to work well, certain preconditions have to be fulfilled. The creation of local level management bodies that would hold the teachers accountable (an egalitarian solution), for instance, requires that the members of these committees are sufficiently aware and empowered to stand up against poorly performing teachers. In other words, there should be a level playing field. The voucher system (a solution fitting the individualist style) requires that there are multiple suppliers and that there is a larger body that keeps checking on quality. In more general terms, competition should be ruly (Moore 2000) [69]. The recruitment of para-teachers (analysed here as an example of the fatalist approach) requires that the ad hoc remedy has a legitimacy and that it triggers the right kind of effects. Table 2 summarizes these preconditions of the various management styles and the extent to which these are realized in the case of addressing teacher absenteeism in India.

To conclude, there are three points we would like to stress. First, since the realization of these preconditions is essential for the strategies to work, they should receive much more serious attention. The fatalist approach is a bit different here - after all, it is based on the idea that there is a large degree of unpredictability anyhow - but for the other three it can be concluded that, in order to allow the strategies to have the desired effects, a lot of effort has to go into the realization of the preconditions. In fact, it makes no sense to introduce the strategies without concurrent efforts to change the social and institutional environment in the necessary direction. The hierarchist approach requires that the governance regime, or more specifically authority, is perceived as legitimate. This draws our attention to several dimensions of good governance, such as efficiency, rule of law, accountability, transparency and responsiveness. Given the extremely uneven level playing field that exists in much of India, any strategy based on the egalitarian management style should come with simultaneous initiatives to address the existing social and economic inequalities. In the case of local level management committees, this would mean serious investments in training and empowering committee members (often people who do not belong to socially dominant groups) to stand up against the poorly performing schools and teachers. An individualist approach requires real choice and also the establishment of a regulatory system. This means that the introduction of a voucher system should be accompanied by initiatives to realize these requirements. The fulfillment of these preconditions is certainly no guarantee of success, but without their (progressive) realization it is naive to expect the strategies can produce the desired results. 
Table 2. Preconditions for Management Styles

\begin{tabular}{|c|c|c|}
\hline Management Approach & Preconditions for Remedies to Work & $\begin{array}{c}\text { Are these Conditions Realized in the Case of } \\
\text { Addressing Teacher Absenteeism in India? }\end{array}$ \\
\hline \hline Hierarchist & Hierarchical authority perceived as legitimate & No, not always (not discussed in the paper) \\
\hline Egalitarian & $\begin{array}{c}\text { Goal of mutuality and participation shared by all } \\
\text { participants } \\
\text { Level playing field }\end{array}$ & $\begin{array}{c}\text { No } \\
\text { No }\end{array}$ \\
\hline Individualist & $\begin{array}{c}\text { Ruly competition } \\
\text { Availability of multiple suppliers }\end{array}$ & Not yet always \\
\hline Fatalist & $\begin{array}{c}\text { Ad hoc or parallel solutions should be accepted } \\
\text { They should also trigger the right effects }\end{array}$ & No ses, sometimes \\
\hline
\end{tabular}

Second, a combination of strategies could perhaps work better than relying on just one strategy. In fact, the most successful effort to address teacher absenteeism that we came across in our review involved a combination of the hierarchist approach (intensification of inspection through the use of cameras) and the individualist approach (income incentives and disincentives) (Duflo and Banerjee 2006) [16].

Finally, all the management approaches imply strategies that 'act on' teachers rather than 'act with' them. It might well be that this is the Achilles' heel of all approaches. They are all premised on the idea that teachers need to be disciplined by external forces. None of these approaches takes the problems, experiences and interpretations of the teachers themselves as the starting point. Based on our own fieldwork, we have come to realize that many teachers are very critical themselves about their behaviour, lack of commitment and absenteeism. Moreover, they have sensible things to say about the reasons that have made them less motivated (Mooij 2008) [9]. This made us realize that what is primarily needed is not a management approach that acts upon teachers, but one that regards teachers not only as part of the problem, but also as part of the solution - and thus as one of the essential actors to be involved in the formulation and implementation of any public management strategy.

\section{REFERENCES}

[1] Ministry of Human Resource Development (MHRD) Annual Report 2005-06. New Delhi: Government of India 2006.

[2] Pratham Resource Centre Annual Status of Education Report (Rural) 2005. Mumbai: Pratham 2006.

[3] Mehrotra S. Reforming elementary education in India: a menu of options. Int J Educ Dev 2006; 26(3): 261-77.

[4] PROBE Team. Public report on basic education in India. New Delhi: Oxford University Press 1999.

[5] Kremer M, Muralidharan K, Chaudhury N, Hammers J, Rogers FH. Teacher absence in India: a snapshot. J Eur Econ Assoc 2005; 3 (23): 658-67.

[6] Shiva KK, De A, Drèze J, Samson M, Dasgupta S. "Education for all' is the policy, but what is the reality? Frontline 2009; 26(6): 1427.

[7] Hood C. The art of the state: culture, rhetoric and public management. New York: Oxford University Press 1998.

[8] Govinda R. An argument for school based management. Proceedings at the second national learning conferenceAutonomous and accountable teacher for quality education. Bangalore, India 2005.

[9] Mooij J. Primary education, teachers' professionalism and social class: about motivation and demotivation of government school teachers in India. Int J Educ Dev 2008; 28: 508-23.

[10] Ramachandran V, Pal M, Jain S, Shekhar S, Sharma J. Teacher motivation in India. Knowledge and skills for development program. Brighton 2005. Available from: www.research4develop ment.info/PDF/Outputs/PolicyStrategy/3888Teacher_motivation_I ndia.pdf [Accessed: 7 May 2010].

[11] Narayan K. Innovative public management strategies to address the problems of teacher absenteeism and poor quality in rural government primary schools in India. MA [dissertation]. Institute of Social Studies: the Hague 2007.

[12] Robinson D, Hewitt T, Harriss J, Eds. Managing Development. Understanding inter-organizational relationships. London: Sage Publications in Association with the Open University 2000.

[13] Clarke P, Jha J. Rajasthan's experience in improving service delivery in education. In: Chand V, Ed. Re-inventing public service delivery in India-selected case studies. New Delhi: Sage Publications and World Bank 2006; pp. 225-65.

[14] Grover S, Singh NH. The quality of primary education: a case study of Madurai and Villupuram districts in Tamil Nadu. India: Harvard Graduate School of Education, Harvard University 2002.

[15] Kremer M, Muralidharan K, Chaudhury N, Hammers J, Rogers FH. Teacher and health care provider absence: a multi country study. Mimeo: World Bank 2004.

[16] Dufflo E, Banerjee A. Addressing absence. J Econ Perspect 2006; 20(1): 117-32.

[17] Hirschman AO. Exit, voice and loyalty. Responses to decline in firms, organizations and states. Cambridge: Harvard University Press 1970.

[18] Majumdar M, Mooij J. Education and inequality in India. London: Routledge forthcoming.

[19] Jha J, Saxena KBC, Baxi CV. Management processes in elementary education: a study of existing practices in selected states in India. New Delhi: European Commission Education Programme Office 2001.

[20] World Bank. Primary education in India. Washington DC: World Bank 1997.

[21] Rao N, Cheng KM, Narain K. Primary schooling in China and India: understanding how socio-contextual factors moderate the role of the state. Int Rev Educ 2003; 49 (1-2): 153-76.

[22] Kremer M, Muralidharan K, Chaudhury N, Hammers J, Rogers FH. Missing in action: teachers and health workers absence in developing countries. J Econ Perspect 2006; 20(1): 91-116.

[23] Kingdon GG, Muzammil M. A political economy of education in India-The case of UP. Econ Polit Wkly 2001; 36(32): 3052-63.

[24] Tooley J, Dixon P. Private schools for the poor: a case study from India. CfBT Res Devel 2003. Available from: www.cfbt.com/PDF/ 91001.pdf [Accessed: 7 May 2010].

[25] Mooij J, Jalal J. Primary education in Delhi, Hyderabad and Kolkata. Governance by resignation, privatisation by default. In: Ruet J, Lama-Rewal TS, Eds. Governing India's Metropolises. New Delhi: Routledge 2009; pp. 135-60.

[26] World Bank. Resuming Punjab's Prosperity: The opportunities and challenges ahead. Washington DC: World Bank 2004.

[27] Drèze J, Sen A. India: development and participation. London and New Delhi: Clarendon Press 2002.

[28] Ghosh A. Education for all-the financing problem. Econ Polit Wkly 1992; 27(14): 679-83.

[29] Rio N. Speech given by the Chief Minister, Nagaland at the $51^{\text {st }}$ Meeting of the National Development Council. New Delhi, India 2005.

[30] Participatory Research in Asia (PRIA). Primary education and panchayati raj institutions. New Delhi: PRIA 2002. 
[31] Bennell P. Teacher motivation and incentives in sub-saharan Africa and Asia. Knowledge and skills for development program. Brighton 2004.

[32] Pritchett L, Pande V. Making primary education work for India's rural poor: a proposal for effective decentralization. social development Paper \# 95 South Asia Series. Washington DC: World Bank 2006.

[33] Vasavi AR, Chand VS, Shukla SR. Blueprint for rural primary education: how viable? Econ Polit Wkly 1997; 32(50): 3181-84.

[34] Vaidyanathan A, Nair PRG. Introduction. In: Vaidyanathan A, Nair PRG, Eds. Elementary education in rural India: a grassroots view. New Delhi: Sage Publications 2001; pp. 23-48.

[35] Noronha A. The community in-charge: shades of experience from Madhya Pradesh. In: Govinda R, Diwan R, Eds. Community participation and empowerment in primary education. New Delhi: Sage Publications 2003.

[36] Sharma R. Dynamics of learning three R's in Madhya Pradesh. Econ Polit Wkly 1997; 32(17):891-901.

[37] Drèze J. Comments on Mahal, Srivastava and Sanan's Paper. In: Dethier J Ed. Governance, decentralization and reform in China, India and Russia. Boston: Kluwer Academic 2000; pp. 271-77.

[38] Comptroller and Auditor General (CAG) of India. Audit Reports (Civil)-Uttar Pradesh, Andhra Pradesh, Chhattisgarh, Himachal Pradesh, Jharkhand, Karnataka, Maharashtra, Orissa, Rajasthan, Punjab, Uttaranchal and West Bengal for the year 2005-06. New Delhi CAG office 2006.

[39] Reddy GM, Bhavani G. Community participation in educational administration: the role of village education committees in Andhra Pradesh. Mimeo forthcoming.

[40] Powis B. Grass roots politics and second wave of decentralisation in Andhra Pradesh. Econ Polit Wkly 2003; 38 (26): 2617-22.

[41] Rana K, Das S, Sengupta A, Rafique A. State of primary education in West Bengal. Econ Polit Wkly 2003; 38(22): 2159-64.

[42] Planning Commission. Towards faster and more inclusive growthan approach to the $11^{\text {th }}$ Five Year Plan [Draft]. New Delhi: Government of India 2006.

[43] Willmore L. Basic education as a human right. Econ Aff 2004; 24(4): 17-21.

[44] Muralidharan K. Public-private partnerships for quality education in India. Seminar September 2006, Issue \#565. Available from: http://www.india-seminar.com/2006/565/565_karthik_muralidharan. htm, [Accessed: 28 May 2010].

[45] Shah P, Braun-Munzinger C. Education vouchers: global experience and India's promise. Policy Rev (1). New Delhi: Center for Civil Society 2006.

[46] Balasubramanian S, Kumar S, Koppar BJ. Primary education in rural areas-an alternative model. Econ Polit Wkly 2003; 38 (34): 3533-36.

[47] Pratham Resource Centre Annual Status of Education Report (Rural) 2006. Mumbai: Pratham 2007.

[48] Muralidharan K, Kremer M. Private and public schools in rural India. Mimeo: Harvard University 2006.

[49] Shukla S, Joshi P. India. In: Phillipson B, Ed. Low-cost private education. Impacts on achieving universal primary education. London: Commonwealth Secretariat 2008.

[50] Levin H. A comprehensive framework for evaluating educational vouchers. Educ Eval Policy Anal 2002; 24 (3):159-74.

[51] Lauglo J. Forms of decentralization and their implication for education. Comp Educ 1995; 31 (1): 5-29.

[52] Indiresan P V. Why not education vouchers? [Online] Business Line. Available from: www.thehindubusinessline.com/2006/11/27/ stories/2006112700900800.htm [Accessed: 7 May 2010]; [Retrieved: 27 October 2007].

[53] Pandey S. Para-teacher scheme and quality education for all in India: the policy perspectives and challenges for school effectiveness. J Educ Teaching: Int Res Pedagogy 2006; 32(3): 319-34.

[54] Fyfe A. The use of para-teachers in developing countries: Trends and impacts. Working Paper \# 252. Geneva: International Labour Organization office 2007.

[55] Govinda R, Josephine Y. Para-teachers in India: a review. New Delhi: National Institute of Educational Planning and Administration 2004.

[56] National University of Educational Planning and Administration (NUEPA). District Information System for Education (DISE)Major Findings 2005-06. New Delhi: NUEPA 2007.

[57] Mehrotra S, Buckland P. Managing school teacher costs for access and quality in developing countries: a comparative analysis. Econ Polit Wkly 2001; 36(49): 4567-79.

[58] Kumar K, Priyam M, Saxena S. Looking beyond the smokescreen: DPEP and primary education in India. Econ Polit Wkly 2001; 36(7): 560-8

[59] Bose S, Chatterjee AV. Primary education in India today: is decentralization the way out? In: Chatterjee AV, Ed. Education and Democracy in India. New Delhi: Manohar 2004.

[60] World Bank. From schooling access to learning outcomes: an unfinished agenda. Washington DC: World Bank Independent Evaluation Group 2006.

[61] Pratichi research team. The delivery of primary education. a study of West Bengal. Pratichi (India) Trust 2002.

[62] Leclercq F. The impact of education policy reforms on the school system: a field study of EGS and other primary schools in Madhya Pradesh. CSH Occasional Paper. New Delhi: Centre de Sciences Humaines 2002.

[63] Duthilleul Y. Lessons learnt in the use of contract teacherssynthesis report. Paris: International Institute for Educational Planning/UNESCO 2005.

[64] Mehrotra S. Reforming public spending on education and mobilising resources: lessons from international experiences. Econ Polit Wkly 2004; 39(9): 987-97.

[65] Sharma R. What manner of teacher: some lessons from Madhya Pradesh. Econ Polit Wkly 1999; 34(25): 1597-607.

[66] Göttelmann-Duret G. The management of primary teachers in South Asia-a synthesis report. Paris: International Institute for Educational Planning/UNESCO 2000.

[67] National Council for teacher education (NCTE). Draft curriculum framework for teacher education. New Delhi: NCTE and NCERT 2006.

[68] Rogers HF, Lopez-Calix J, Chaudhury N et al. Teacher absence and incentives in primary education: results from a national teacher tracking survey in Ecuador. Excerpt from the report Ecuador: creating a fiscal space for poverty reduction-a fiscal management and public expenditure review 2004; Vol. 2. pp 136-62. Available from: http://siteresources.worldbank. org/DEC/Resources/37912 Ecuador.Teacher.Absenteeism.August13.2004.pdf [Retrieved 10 October 2007].

[69] Moore M. Competition within and between organizations. In: Robinson D, Hewitt T, Harriss J, Eds. Managing development. Understanding inter-organizational relationships. London: Sage Publications in Association with the Open University 2000; pp. 89114.

This is an open access article licensed under the terms of the Creative Commons Attribution Non-Commercial License (http://creativecommons.org/licenses/by-nc/ $3.0 /$ ) which permits unrestricted, non-commercial use, distribution and reproduction in any medium, provided the work is properly cited. 